\title{
The Study of Mobile Learning Readiness in Rural Area: Case of North-Eastern of Thailand
}

\author{
Thipsuda Wongkhamdi \\ Technopreneurship and Innovation \\ Management Program, \\ Graduate School, \\ Chulalongkorn University, Thailand \\ Thipsuda.W@student.chula.ac.th
}

\author{
Nagul Cooharojananone \\ Department of Mathematics and \\ Computer Science \\ Faculty of Science \\ Chulalongkorn University, Thailand \\ Nagul.C@chula.ac.th
}

\author{
Jintavee Khlaisang \\ Department of Educational \\ Technology and Communications \\ Faculty of Education \\ Chulalongkorn University, Thailand \\ jintavee.m@g.chula.edu
}

\begin{abstract}
Thai government is now encouraging each rural sub-district (Tambon) to be able to gain the income from selling their One Tambon One Product (OTOP) through the ecommerce. To be able to do that, local community members should have a knowledge of e-commerce. The easiest way would be learning from a mobile phone (mobile learning). In this paper, we study the readiness of mobile learning in the rural sub-district area. We collected data from 164 participants from the OTOP seminar in the Northeastern of Thailand. From the statistical data shows that $88.4 \%$ of the Thais in rural subdistrict have smart phones that connect to an internet most of the time. Most of them use mobile phones to call, do social network and also sending pictures or videos on daily routine. Even they do not use mobile phones for learning, but $\mathbf{8 9 . 5 \%}$ show that they are willing and intending to learn through mobile phones. The mobile learning is more flexible and can be used anytime and anywhere which is appropriate to their life style. The study of the mobile learning readiness let us know that Thais in rural sub-district should learn e-commerce content from mobile phones. The next challenge would be how to design the content for Thais in the rural sub-district.
\end{abstract}

Keywords-Mobile Learning; Readiness; Acceptance; Rural sub-district; Local Community Enterprise; OTOP; SMEs.

\section{INTRODUCTION}

During the last decade, the ITU has estimated the number of mobile users in the world. It has been significantly increased. From the latest report of International Telecommunications Unit [1] refers that there were more than 7,000 million users in the world with a mobile line by the end of the year 2016.Especially, in Thailand from National Broadcasting and Telecommunications Commission [2] refers that at the beginning of the year in 2017, there were more than 90.7 million users, compared with the end of the year in 2016, there were 90 million users. It can be seen that the number of mobile users is increasing and are on the rise every year. Including information from the survey of Thailand Electronic Transactions Development Agency (Public Organization) [3] refers that Thai people have an average of internet usage about 6.4 hours/day. There is users access internet through smart phone about $85.5 \%$, which is more than via personal computer with $62.0 \%$ and via notebook around $48.7 \%$ and the amount of internet activity is number 1 is using social network, followed by using
YouTube, using to search information and reading E-book. These details indicate that number 2, 3 and 4 is related to the subject of learning by seeking knowledge.

It can be seen that ICT enabled people to study remotely. Wireless devices are now changing E-learning to M-learning with increasing popularity. Because of advantages of $\mathrm{M}$ learning is a higher convenience, mobility, enhanced communication, or attractive new technology [4]. As a result of the change in ICT, the learning process is no longer reliant on traditional teaching methods, but it should be expanded to include new technologies and forms of learning, such as mobile learning (M-learning) which is new and interesting methods of learning [5]. Even though, UNESCO has considered mobile devices as a platform to offer equal opportunities in education among different countries [6].

Currently, Thai government is promoting OTOP community enterprise to increase the knowledge of ecommerce to help the community can adapt to the changing of economic, social and technology of the world. Because of the main problem of OTOP community enterprise is marketing in both of the development of knowledge, creating a marketing strategy, creating an innovative, finding new markets including no distribution channel via E-commerce [7] , M-learning has been considered as an interesting option to provide E-commerce knowledge to the OTOP community enterprise in the rural area, because learners can learn in the remote place and can learn anywhere and anytime, according to the learners need.

The objectives of this study are to examine the perception of using mobile technology and to identify the acceptance of m-learning among Thai local community Enterprises and also to find out m-learning opportunities. The results of this research are expected to be used in the design and development of mobile learning systems to suit the current condition of OTOP community enterprise.

\section{REVIEW OF OTOP COMMUNITY ENTERPRISE THAILAND CONTEXT}

OTOP Project Concept (One Tambon One Product)

OTOP project is established for each community to use local wisdom in product development by the government will help and support with modern knowledge and managed to 
link products from community to market both in the country and abroad with trading systems networks and the internet. To promote and support the local development process, build a strong, self-reliant community that engages people in making money by using local wisdom resources. To develop a product and quality services are featured and value-added selling points are needed both domestically and internationally. The objectives is to: 1 . To create jobs in the community. 2. To strengthen the community. People can think and do it by themselves to develop community. 3. To promote local wisdom. 4. To promote human resource development. 5. To promote community initiative in product development in accordance with the way of life and local culture [8].

\section{OTOP Product Category}

The One Tambon One Product project is divided into 5 categories as follows: 1. Food 2. Beverage 3. Clothing and apparel 4. Appliance, accessory and souvenir 5. Herb

\section{Product Level}

Selection of the OTOP Product Champion as specified in one of the best selections of the OTOP product guidebook consists of various factors, both the general criteria with 5 parts and the specific criteria that the product level is set to 5 levels as follows: 5-star rating of 90 points up. 4-star rating from 70-89 points, 3-star rating from 50- 69 points, 2-star rating from 30- 49 points, 1-star rating from below 30 points.

Currently, the Community Development Department, there are three groups of OTOP manufacturers:

\section{SMCE or Small and Micro Community Enterprise}

Refers to a community enterprise engaged in the production of goods, service or other work that performed by a party by they share a common lifestyle, and incorporate to run a business whether a corporation or not is a legal entity in making money and to self-reliance of the family and community. The meaning of Small and Micro Community Enterprise is "Community capital" creatively for self-reliance

\section{SMEs}

Enterprise means a manufacturing enterprise; service provider, wholesale and retail businesses by the enterprise covers three major groups: 1 . Production sector that covers production in the agricultural sector, (Agricultural processing), Industry sector, Manufacturing sector and mining 2. Trading sector that covers wholesale and retail businesses 3. Service sector

\section{Self-employed business}

Self-employed business is a business carried out by a person who is responsible for all liabilities incurred. A singleperson entity owns or invests alone to control all operations. When a business is successful, it is profitable to receive only one. At the same time, one must accept the risk of loss as well. These types of businesses are available throughout the country. The business is most popular and oldest business with complex operations, high flexibility in decision making, but the business is smaller than any other business.

\section{REVIEW OF MOBILE LEARNING Mobile learning and readiness}

Mobile learning (m-learning) is a form of learning which leverages on the mobile device's portability and affordability Yamaguchi [9]. M-learning is considered as a form of teaching and learning that occurs through mobile devices such as mobile phones, Personal Digital Assistants (PDA), and others. M-learning allows learners to access computerbased learning anytime and anywhere and as stated by Traxler [10], and m-learning overcomes poor internet connectivity, frequent power disruptions and low PC support and availability, especially in remote and rural areas, because it is strengthened by the vigor and talent of the mobile phone networks.

In addition, Wagner [11] states that the use only technology is insufficient to ensure success in learning. Another important factor is the technological considerations.

There are two aspects in readiness of learners (including attitude and acceptance) is also crucial. It is necessary to determine how learners will accept M-learning, how they are ready in terms of technology and readiness for a new learning innovation [12]. There are several researchers conducted on mobile learning, readiness to study learners' readiness and acceptance in the use of mobile technology for learning in different contexts [2], [4], [13], [14], [15], [16].

\section{METHODOLOGY}

The instruments are used for the survey, which was the structured questionnaire to collect data from 164 respondents. The questionnaire was included the demographic data, current mobile phone usages including using mobile feature and perspective of participants about Mlearning by using a five-point Likert scale ranging. Questionnaires were estimated by the Cronbach Alpha coefficient to reliability and found that Cronbach Alpha is over 0.7 that means this questionnaire is reliable.

The data obtained from the questionnaire was analyzed by using a fundamental descriptive method. The meaning of the mean value in table II, V, VI is defended as follow:

$1.00-1.80$ refers to lowest

$1.81-2.60$ refers to low

2.61-3.40 refers to moderate

3.41-4.20 refers to high

4.21-5.00 refers to highest

\section{RESEARCH SAMPLE}

The participants in this research are members of OTOP community in Nakhon Ratchasima province in the Northeastern of Thailand. Their products are rated as 4-5 stars quality. The sample was selected by random sampling. The participants are 20- 70 years old.

TABLE I. The description of demographic information of the study

\begin{tabular}{|l|c|r|}
\hline \multicolumn{1}{|c|}{ Characteristic } & Frequency & Percent \\
\hline Gender & 97 & 59.15 \\
\hline Male & 67 & 40.85 \\
\hline Female & 26 & 15.85 \\
\hline Age & 38 & 23.17 \\
\hline 20 and less than 30 & 63 & 38.41 \\
\hline 30 and less than 40
\end{tabular}




\begin{tabular}{|c|c|r|}
\hline Characteristic & Frequency & Percent \\
\hline 50 and less than 60 & 25 & 15.24 \\
\hline Over 60 Total & 12 & 7.32 \\
\hline To & 164 & 100.0 \\
\hline
\end{tabular}

Table I shows the distribution of the sampling according to demographic variables. It shows a total of 164 Thais, where $59 \%$ are men and $41 \%$ are women. Most of the age range is 40-50 years old.

\section{FINDINGS}

The objectives of this research is to understand the readiness of mobile learning in E-commerce based on usage behavior, mobile device knowledge, and daily activities made using mobile devices.

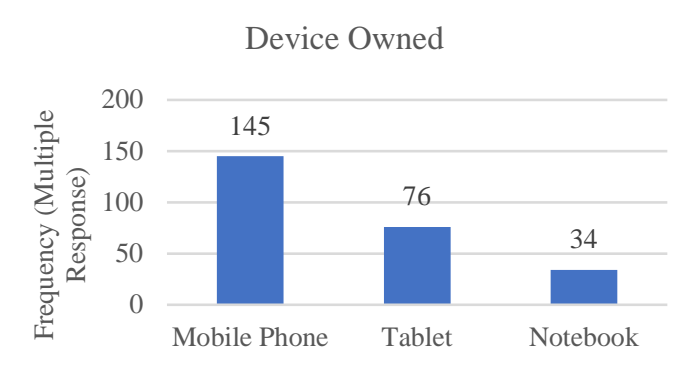

Fig. 1. Device Owned (Can own more than one device)

Figure 1 shows the mobile device that the community enterprise possesses. It can be seen from the sample of 164 respondents with 145 mobile phones and there are 76 people who have tablets and there are 34 people who have the notebook. It shows that currently, entrepreneurs in the countryside start to use mobile phone widely.

Operating system of owned mobile phone

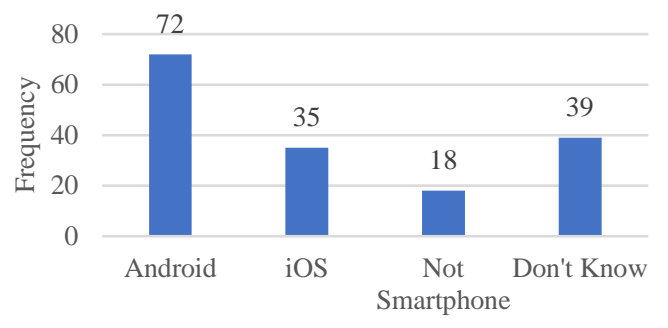

Fig. 2. Operating system of owned mobile phone

Figure 2 shows the operating system of owned mobile phones of the community enterprise group. Most people used Android around 72 people, followed by iOS around 35 people and 18 people who did not use Smartphone. This means that they will only use the phone for calls and SMS, as well as those who do not know what their operating system around 39 people.

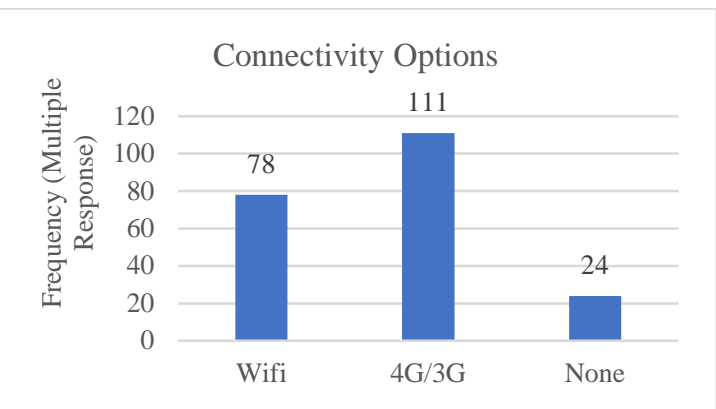

Fig. 3. Connectivity Options

Figure 3 shows that there were 111 respondents who have mobile phones and have purchased 4G / 3G internet usage hours, followed by the internet usage of WIFI connections around 78 people, and there are still people who did not use internet around 24 people. That means most people are ready to connect to the internet and online access to news information at any time.

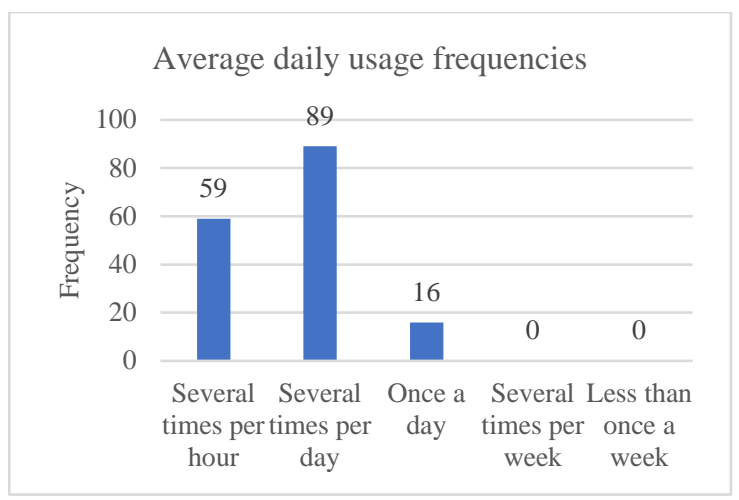

Fig. 4. Average daily usage frequencies

Figure 4 shows that most of the people use mobile phone many times/day, followed by their use mobile phone many times/hour, and at least everyone uses the mobile phone once a day. That shows that mobile phone is part of the regular activities of respondents and it is likely that user will have the ability to use more features of the mobile phone has increased.

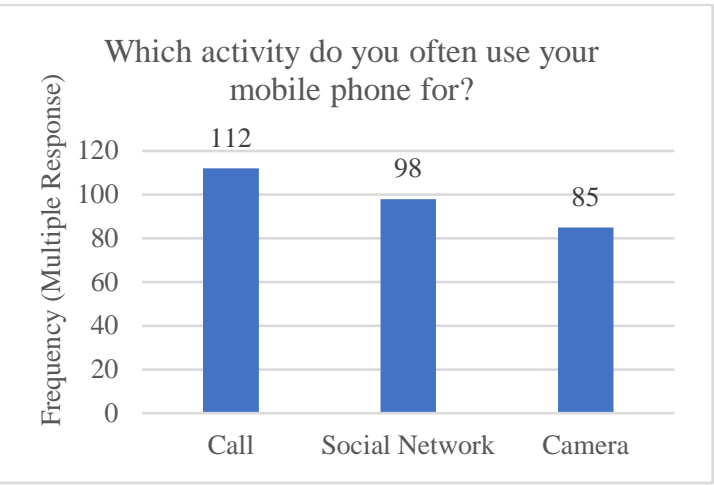

Fig. 5. Activity often use mobile phone for 
TABLE II. Mobile device using experience

\begin{tabular}{|c|c|c|c|c|c|c|c|c|}
\hline Mobile device using experience & Very often & Always & Sometimes & Almost never & Never & $\bar{x}$ & SD & Level \\
\hline \multirow[t]{2}{*}{ To call } & 48 & 67 & 20 & 11 & 0 & \multirow[t]{2}{*}{4.04} & \multirow[t]{2}{*}{0.88} & \multirow[t]{2}{*}{ high } \\
\hline & $32.9 \%$ & $45.9 \%$ & $13.7 \%$ & $7.5 \%$ & 0 & & & \\
\hline \multirow[t]{2}{*}{ To chat (e.g. Line) } & 53 & 62 & 22 & 9 & 0 & \multirow[t]{2}{*}{4.09} & \multirow[t]{2}{*}{0.87} & \multirow[t]{2}{*}{ high } \\
\hline & $36.3 \%$ & $42.5 \%$ & $15.1 \%$ & $6.2 \%$ & 0 & & & \\
\hline \multirow{2}{*}{$\begin{array}{l}\text { To download and play games or applications from } \\
\text { the web }\end{array}$} & 37 & 56 & 24 & 21 & 8 & \multirow[t]{2}{*}{3.64} & \multirow[t]{2}{*}{1.17} & \multirow[t]{2}{*}{ high } \\
\hline & $25.3 \%$ & $38.4 \%$ & $16.4 \%$ & $14.4 \%$ & $5.5 \%$ & & & \\
\hline \multirow[t]{2}{*}{ To take photos } & 47 & 71 & 23 & 5 & 0 & \multirow[t]{2}{*}{4.10} & \multirow[t]{2}{*}{0.78} & \multirow[t]{2}{*}{ high } \\
\hline & $32.2 \%$ & $48.6 \%$ & $15.8 \%$ & $3.4 \%$ & 0 & & & \\
\hline \multirow{2}{*}{$\begin{array}{l}\text { To send pictures or video to other people or upload } \\
\text { them online }\end{array}$} & 54 & 63 & 23 & 6 & 0 & \multirow[t]{2}{*}{4.13} & \multirow[t]{2}{*}{0.82} & \multirow[t]{2}{*}{ high } \\
\hline & $37.0 \%$ & $43.2 \%$ & $15.8 \%$ & $4.1 \%$ & 0 & & & \\
\hline \multirow[t]{2}{*}{ To send or receive email } & 21 & 23 & 37 & 48 & 17 & \multirow[t]{2}{*}{2.88} & \multirow[t]{2}{*}{1.23} & \multirow[t]{2}{*}{ moderate } \\
\hline & $14.4 \%$ & $15.8 \%$ & $25.3 \%$ & $32.9 \%$ & $11.6 \%$ & & & \\
\hline \multirow{2}{*}{$\begin{array}{l}\text { To use social networking software on the internet } \\
\text { (e.g. Facebook, Twitter, Instagram etc.) }\end{array}$} & 45 & 64 & 23 & 14 & 0 & \multirow[t]{2}{*}{3.96} & \multirow[t]{2}{*}{0.92} & \multirow[t]{2}{*}{ high } \\
\hline & $30.8 \%$ & $43.8 \%$ & $15.8 \%$ & $9.6 \%$ & 0 & & & \\
\hline $\begin{array}{l}\text { To access information for teaching and learning } \\
\text { purposes }\end{array}$ & $16.4 \%$ & $18.5 \%$ & $38.4 \%$ & $18.5 \%$ & $8.2 \%$ & 3.16 & 1.16 & moderate \\
\hline \multirow[t]{2}{*}{ To create/edit audio and video } & 13 & 15 & 45 & 59 & 14 & \multirow[t]{2}{*}{2.68} & \multirow[t]{2}{*}{1.07} & moderate \\
\hline & $8.9 \%$ & $10.3 \%$ & $30.8 \%$ & $40.4 \%$ & $9.6 \%$ & & & \\
\hline
\end{tabular}

Figure 5 shows the most common activity is call around 112 people, followed by people around 98 people who use mobile phone for playing social network, and there were 85 people who use mobile phone to photograph. It shows that if the design of a mobile learning system can be designed with the social network more. Since the user is currently active, including a feature to upload information to help with learning

Table II shows the users' experience with mobile devices. Most of participants use mobile device to upload or send photos and videos online $(\bar{x}=4.13)$. This is due to the habits of Thais that prefer to exchange photos instead of text such as photos that contain greeting and congratulatory messages. Next, participants use of mobile devices to photograph $(\bar{x}=4.10)$. Due to current mobile devices is affordable prices and the growth in the user's familiarity to photograph through mobile devices. Then, the participants use mobile device to chat or message interface (e.g. LINE) $(\overline{\boldsymbol{x}}=4.09)$. Currently, Thai people preferred to communicate through the LINE application even for business. They use LINE more than the E-mails in the past years. The use of voice communication or dialing is $(\bar{x}=4.04)$ due to the basic use of mobile devices, what they were built for. In fifth place is the familiarity with the interface of the mobile devices $(\overline{\boldsymbol{x}}$ =3.96). This includes the use of online social networking applications (e.g. Facebook, Twitter, Instagram, etc.). Thai people use social networking platforms such as Facebook a lot whether it's for business or sharing of personal status to family members. Therefore, if we were to design an interface on a mobile learning device, the device should strongly support social networking applications. In sixth place is the function to download gaming applications from the web $(\overline{\boldsymbol{x}}$ =3.46). Gaming is one of the activities that is very popular amongst users from different age ranges. It would be beneficial to design a mobile learning device that is gamelike to induce interests from the users. On the other hand, in the seventh place, are the users whom are not familiar with accessing teaching and learning materials that are available for them $(\overline{\boldsymbol{x}}=3.16)$. This may be due to the fact that most of them are busy with their main responsibilities such as sales or negotiations with their clients. So unfortunately, they do not have enough time to learn. In ninth place, the users' ability to send or receive e-mails $(\overline{\boldsymbol{x}}=2.88)$ and the ability to create/edit audio and video files $(\overline{\boldsymbol{x}}=2.68)$. We can see that our participants are less familiar with this kind of usage. Therefore, if we were to design an interface for a mobile learning device, we should consider whether or not our users are familiar in these areas. Looking from another perspective, those who are involved in educating the community and enterprises should be able to organize workshops to help educate other users in these areas.

TABLE III. Use mobile phone for learning or educational purposes

\begin{tabular}{|c|c|c|}
\hline $\begin{array}{c}\text { Use mobile phone for learning or } \\
\text { educational purposes }\end{array}$ & Frequency & Percentage \\
\hline Yes & 124 & 84.9 \\
\hline No & 22 & 15.1 \\
\hline Total & 146 & 100.0 \\
\hline
\end{tabular}

Table III shows that the most of participants use mobile phone for learning purposes $(124=84.9 \%)$ and some participants not use only $(22=15.1 \%)$ indicates that the community uses their mobile phone to seek knowledge. Most of them will learn how to increase sales from YouTube channel or Facebook.

TABLE IV. Amount time spent on mobile phone for learning/education
\begin{tabular}{|c|c|c|}
\hline $\begin{array}{c}\text { Amount time spent on mobile phone } \\
\text { for learning/education }\end{array}$ & Frequency & Percentage \\
\hline Less than 1 hour & 71 & 69.6 \\
\hline 1-3 hours & 21 & 20.6 \\
\hline 3-6 hours & 6 & 5.9 \\
\hline More than 6 hours & 4 & 3.9 \\
\hline Total & 102 & 100.0 \\
\hline
\end{tabular}

Table IV shows that people spent time on mobile phones for learning or educational purposes less than 1 hour (71 = $69.6 \%)$, followed by about $1-3$ hours $(21=20.6 \%)$ and 3-6 
hours, there are only 6 people and the last, only 4 people who use their mobile phone for learning more than 6 hours. This shows that respondents did not take much time to get to seek the knowledge through mobile phone.

Table V shows the users' acceptance of mobile learning devices. From our survey, we found out that we have received high acceptance in all areas. Coming up with the highest score is the fact that users think that m-learning will be able to provide new methods of learning $(\bar{x}=3.92)$, all of which include those whom enjoy and open to learn new things through new mediums. Secondly, our participants agreed that m-learning will increase the quality of learning $(\bar{x}=3.90)$ because they are not stationed in one place all the time and they will have to commute to sell their products. They believe that mobile learning devices has the advantages they need, to be able to learn anywhere at anytime. In third place, participants are confident while using their mobile phones for learning $(\overline{\boldsymbol{x}}=3.79)$. This is because they are already familiar with their personal mobile devices. In fourth place is the fact that the participants prefer to use their personal devices for their own learning $(\overline{\boldsymbol{x}}=3.77)$.

TABLE V. Acceptance of mobile learning

\begin{tabular}{|l|c|c|c|c|c|c|c|c|}
\hline \multicolumn{1}{|c|}{ Acceptance of mobile learning } & Strongly agree & Agree & Not sure & Disagree & Strongly disagree & $\overline{\boldsymbol{x}}$ & SD & Level \\
\hline $\begin{array}{l}\text { I like to use my own mobile phone for my own } \\
\text { learning. }\end{array}$ & 45 & 49 & 27 & 23 & 2 & 3.77 & 1.10 & high \\
\hline & $30.8 \%$ & $33.6 \%$ & $18.5 \%$ & $15.8 \%$ & $1.4 \%$ & & & \\
\hline $\begin{array}{l}\text { I am confident when using my mobile phone } \\
\text { for learning. }\end{array}$ & 43 & 54 & 28 & 17 & 4 & 3.79 & 1.08 & high \\
\hline \multirow{2}{*}{ M-learning will increase the quality of learning. } & $29.5 \%$ & $37.0 \%$ & $19.2 \%$ & $11.6 \%$ & $2.7 \%$ & & & \\
\hline
\end{tabular}

TABLE VI. Mobile learning opportunities

\begin{tabular}{|c|c|c|c|c|c|c|c|c|}
\hline Mobile learning opportunities & Strongly agree & Agree & Not sure & Disagree & Strongly disagree & $\bar{x}$ & SD & Level \\
\hline \multirow{2}{*}{$\begin{array}{l}\text { M-learning will bring new opportunities for } \\
\text { learning. }\end{array}$} & 44 & 61 & 31 & 10 & 0 & 3.95 & 0.89 & high \\
\hline & $30.1 \%$ & $41.8 \%$ & $21.2 \%$ & $6.8 \%$ & 0 & & & \\
\hline \multirow[t]{2}{*}{ M-learning can save my time. } & 76 & 49 & 16 & 5 & 0 & 4.34 & 0.81 & highest \\
\hline & $52.1 \%$ & $33.6 \%$ & $11.0 \%$ & $3.4 \%$ & 0 & & & \\
\hline \multirow{2}{*}{$\begin{array}{l}\text { I find m-learning easy, as it is possible to learn } \\
\text { what I want. }\end{array}$} & 32 & 37 & 67 & 10 & 0 & 3.62 & 0.90 & moderate \\
\hline & $21.9 \%$ & $25.3 \%$ & $45.9 \%$ & $6.8 \%$ & 0 & & & \\
\hline \multirow[t]{2}{*}{ M-learning meets my needs and interests. } & 59 & 48 & 18 & 11 & 10 & 3.92 & 1.20 & high \\
\hline & $40.4 \%$ & $32.9 \%$ & $12.3 \%$ & $7.5 \%$ & $6.8 \%$ & & & \\
\hline \multirow{2}{*}{$\begin{array}{l}\text { M-learning enables me to get feedback from } \\
\text { teachers more quickly than before. }\end{array}$} & 42 & 54 & 45 & 5 & 0 & 3.91 & 0.85 & high \\
\hline & $28.8 \%$ & $37.0 \%$ & $30.8 \%$ & $3.4 \%$ & 0 & & & \\
\hline \multirow{2}{*}{$\begin{array}{l}\text { M-Learning is more flexible than traditional } \\
\text { learning; it can be anytime and anywhere. }\end{array}$} & 78 & 43 & 14 & 11 & 0 & 4.29 & 0.92 & highest \\
\hline & $53.4 \%$ & $29.5 \%$ & $9.6 \%$ & $7.5 \%$ & 0 & & & \\
\hline \multirow{2}{*}{$\begin{array}{l}\text { It is possible to achieve my educational aims } \\
\text { through m-learning. }\end{array}$} & 40 & 55 & 31 & 12 & $8 \%$ & 3.73 & 1.12 & high \\
\hline & $27.4 \%$ & $37.7 \%$ & $21.2 \%$ & $8.2 \%$ & $5.5 \%$ & & & \\
\hline
\end{tabular}

Table VI. We will consider the opportunity to use Mlearning. First, in highest level, they believe that m-learning can save their time $(\bar{x}=4.34)$. Secondly, M-learning is more flexible than traditional learning methods; its mobility allows users to study anywhere, at any time $(\bar{x}=4.29)$. They are not limited in learning in classrooms. Even when they are busy, they can arrange the time table to whenever they are free to learn, pause and come back later. This is because the advancement of m-learning that gives its users freedom and mobility, it meets the needs and lifestyles of today's community enterprise. In third place, also in high level, is that users believe that m-learning will bring new opportunities for them to learn $(\bar{x}=3.95)$. This means the opportunity to obtain new knowledges such as digital marketing, writing contents for clients, using online channels to establish social networking such as Facebook and LINE which are very popular social networking platforms in Thailand. In fourth place, M-learning meets the users' needs and interests ( $\overline{\boldsymbol{x}}$ =3.92). They believed that m-learning the mobility of $\mathrm{m}$ learning will enhance their e-commerce market, help increase their marketing channels and public relations, resulting in higher income. In fifth place, they believe that m-learning enables them to easily obtain feedbacks from their teachers than before $(\overline{\boldsymbol{x}}=3.91)$. M-learning is not limited to learning from within the wall of a classroom. When the students/users have questions of doubts, they can reach out for answers with ease. Especially, in LINE application where teachers often use to contact student and other applications also include Facebook Messenger, Facebook Fan Page, and Facebook groups that were created with agreements between students and teachers. In sixth place, users believed that it is possible to achieve their educational aims through M-learning $(\bar{x}=3.73)$. This is noteworthy because $21.2 \%$ of the respondents marked 'Not sure'. This will be a challenge for the system's designers and other relevant team members in reassuring the users and built trust for M-learning. Lastly, at moderate, users believe that M-learning is easy, as it is possible to learn what they want $(\bar{x}=3.62)$. They believe that M-learning is not difficult to use because they can use their own mobile devices that they are already familiar with. Another noteworthy point is that $45.9 \%$ one the users choose 'Note sure'. This is due to the face that they have not 
experienced m-learning through their own mobile devices. Furthermore, some people are not certain whether their mobile devices are capable of doing more that just making phone calls and social networking. They are unaware that another use of mobile devices is to seek knowledge. So, this is the duty of the instructor to inspire and motivate them to learn. All in all, including the advantages of m-learning as mentioned above, users believe that their learning goals can be achieved through m-learning.

\section{CONCLUSION}

This paper presents mobile usage conditions in nowadays and findings of the possibility of using m-learning with Thai local community enterprise (OTOP). From the respondents' analysis refers that most of the operators have mobile phones and most of the mobile phones are smart phones that can be used to take photos and play social networks. They have Internet access by connecting via Wi-Fi and sometimes buying 4G / 3G services and having frequent mobile phone usage many times per day, they are getting used to their mobile features for calls, social networks and take photos.

In terms of user experience, users are familiar with sending pictures or video to other people, or upload online and taking photos and chatting (e.g. Line). Most of users ever used mobile for learning purposes, but they spent time to learning less than an hour.

During the term of acceptance of m-learning, most of the respondents believed that m-learning provided them with new methods of learning and believed that M-learning will increase the quality of learning and also to use their own mobile phone for their own learning.

In terms of m-learning opportunities found that most of respondents think that m-learning can save their time as much as possible due to the lifestyle. Learning from the mobile phones that they use regularly, it can help them save time without having to travel to learning in the classroom, which confirms that it meets the needs, followed by m-learning is more flexible than traditional learning; it can be anytime and anywhere which is a real need that they strongly agree that m-learning meets their needs and interests.

These findings can help policy maker or relevant person in planning, designing OTOP community enterprise learning systems more effective.

\section{FUTURE WORK}

In Thailand, smart phone has been widely used for 2-3 years and is rapidly expanding both the whole number of mobile phone users and the operation of the internet provider is expanding to cover rural areas as well as data service charges dropped significantly. Therefore, people can use the Internet more easily, anytime and anywhere.

After we have conducted and studied the readiness of mobile learning, our next research should approach the design aspect. This includes how the contents will be displayed on the mobile devices so that it is appropriate for the users' applications.

\section{REFERENCES}

[1] International Telecommunication Union (ITU), May 2016. "ICT Facts and Figures 2016”, http://www.itu.int/en/ITU-D/Statistics/Documents /facts/ICTFactsFigures2016.pdf Accessed 1 May 2017.

[2] National Broadcasting and Telecommunications Commission of Thailand (NBTC), May 2017. "Mobile users in Thailand Q1 2017”, http://www.veedvil.com/featured/mobile-users-in-thailand-q1-2017/ Accessed 2 May 2017.

[3] Thailand Electronic Transactions Development Agency (Public Organization) (ETDA), August 2016. "Thailand Internet user Profile 2016”, https://www.etda.or.th/download-publishing/57/ Accessed 4 May 2017.

[4] H. Kopackova, R. Bilkova. "Mobile devices in learning - Are students ready for the change?” 2014 IEEE 12th International Conference on Emerging eLearning Technologies and Applications (ICETA). 4-5 December 2014. Emerging eLearning Technologies and Applications (ICETA), Stary Smokovec, Slovakia; pp. 39-44.

[5] Almutairy S., Davies T., Dimitriadi Y. "The readiness of applying mlearning among Saudi Arabian students at Higher Education”. 2014 International Conference on Interactive Mobile Communication Technologies and Learning (IMCL). 13-14 November 2014. Interactive Mobile Communication Technologies and Learning, Thessaloniki, Greece; pp. 102-106

[6] M. West and C. H. Ei, Reading in the mobile era: a study of mobile reading in developing countries: UNESCO, 2014.

[7] Chiarakul T., June 2015. "The Problems and the Adaption of OTOP to AEC”, http://www.bu.ac.th/knowledgecenter/executive_journal/ jan_june_14/pdf/aw18.pdf Accessed 4 May 2017.

[8] Community Development Department of Thailand, June 2016. “OTOP” , http://www.cdd.go.th/content/download/ documents Accessed 4 May 2017.

[9] Yamaguchi, T., 2005. "Vocabulary learning with a mobile phone”. Program of the 10th Anniversary Conference of Pan-Pacific Association of Applied Linguistics, Edinburgh, UK.

[10] Traxler, J., 2007. "Making Good Use of Mobile Phone Capabilities”, http://www.elearningafrica.com/newsportal/english/news70.php Accessed 8 May 2017.

[11] Wagner, E. D., 2005. "Enabling Mobile Learning. Educause Review”, pp. 41-52. , http://connect.educause.edu/Library/EDUCAUSE+ Review/EnablingMobileLearning/40549?time=1229470759 Accessed 8 May 2017.

[12] Almutairy S., Davies T., Dimitriadi Y. "A STUDY ON LEARNER READINESS FOR MOBILE LEARNING AT OPEN UNIVERSITY MALAYSIA”.IADIS International Conference Mobile Learning 2009. 26-28 Febuary 2009. IADIS International Conference Mobile Learning, Barcelona, Spain; pp. 151-157.

[13] Fazlina S., Manap A. A., Rias R. M. "Mobile Learning Awareness among Students at Higher Learning Institutes: A Case Study”. 2013 International Conference on Informatics and Creative Multimedia (ICICM). 4-6 September 2013. Informatics and Creative Multimedia, Kuala Lumpur, Malaysia; pp. 226-229.

[14] Klaben A., Eibrink-Lunzenauer M., Gloggler T. "Requirements for Mobile Learning Applications in Higher Education”. 2013 IEEE International Symposium on Multimedia (ISM). 9-11 December 2013. Multimedia (ISM), Anaheim, CA, USA; pp. 492-497.

[15] Alfarani L. A. "Influences on the adoption of mobile learning in saudi women teachers in higher education”. 2014 International Conference on Interactive Mobile Communication Technologies and Learning (IMCL). 13-14 November 2014. Interactive Mobile Communication Technologies and Learning (IMCL), Thessaloniki, Greece; pp. 30-34.

[16] Poong, Y. S.; Yamaguchi, S.; Takada, J. "Possibility to Use Mobile Learning to Promote World Heritage Site Preservation Awareness in Luang Prabang, Lao Pdr: a Readiness Study”. ISPRS Annals of Photogrammetry, Remote Sensing and Spatial Information Sciences 2013. 2-6 September 2013. ISPRS Annals of Photogrammetry, Remote Sensing and Spatial Information Sciences, Strasbourg, France; pp. 247-252. 